\title{
Foliar gas exchange, fruit quality and water use efficiency of cape Gooseberry under different irrigation depths and mulching at greenhouse conditions
}

\author{
Eduardo Augusto Agnellos Barbosa ${ }^{1}$, Ricardo Antonio Ayub ${ }^{2}$, Ângela da Luz \\ Isabela Leticia Pessenti ${ }^{4}$, André Belmont Pereira ${ }^{5}$ \begin{abstract}
Ratio along with the lowest total acidity observed.
\end{abstract} \\ Abstract - The current study aimed at evaluating gas exchanges, yield, water use efficiency and fruit \\ quality of cape gooseberry in response to different irrigation depths with or without mulching of oat \\ residues on pots at greenhouse conditions. Four irrigation depths were tested: $50 \%, 100 \%, 125 \% \mathrm{e}$ \\ $150 \%$ of reference evapotranspiration (ETo). Leaf gas exchanges were evaluated by an infrared gas \\ analyzer at different stages of the crop. Throughout the harvest, yield per plant and yield components \\ were assessed in conjunction with water-use efficiency (WUE) and fruit quality responses. Stomata \\ conductance at the flowering and fructification stages showed a smaller limitation under the treatments \\ 125 and $150 \%$ ETo. It should be noticed that the aforementioned treatments increased in $83 \%$ fresh \\ fruit mass per plant in comparison to $50 \% \mathrm{ETo}$. We found a higher instantaneous water-use efficiency \\ throughout flowering under $150 \% \mathrm{ETo}$, as well as at the fructification under $125 \% \mathrm{ETo}$ treatments. \\ Nevertheless, under $125 \%$ ETo conditions without mulching the greatest WUE was found, whereas the \\ lowest WUE was obtained under the 50\%ETo treatment with no mulching. The treatment $125 \%$ ETo \\ resulted in the highest $\mathrm{SS}$ and $\mathrm{pH}$, whilst the treatment $150 \% \mathrm{ETo}$ with mulching evidenced the highest \\ Index terms: Physalis peruviana L.; Water stress; Stomata conductance; Photosynthesis; Fruit yield.

\section{Trocas gasosas, qualidade dos frutos e eficiência do uso da água da Fisális em função de lâminas de irrigação e cobertura dos vasos sob ambiente protegido}

Corresponding author: eduardo.agnellos@gmail.com

Received: January 032019 Accepted: June 04, 2019

Copyright: All the contents of this journal, except where otherwise noted, is licensed under a Creative Commons Attribution License.

\section{(cc) $\mathbf{E} \mathrm{Y}$}

\begin{abstract}
Resumo- O presente trabalho teve o objetivo de avaliar as trocas gasosas, o rendimento, a eficiência do uso da água e a qualidade dos frutos de physalis, em função de diferentes lâminas de irrigação, com a presença ou a ausência de cobertura de palhas de aveia, nos vasos sob ambiente protegido. Foram testadas quatro lâminas de irrigação baseadas em $50 \%, 100 \%, 125 \%$ e $150 \%$ da ETo. A cobertura dos vasos foi realizada com palha de aveia. As trocas gasosas nas folhas foram avaliadas por intermédio de um analisador de gases infravermelho, nos diferentes estágios fenológicos da cultura. Durante a colheita, a produção por planta e os componentes de rendimento foram avaliados em associação com a eficiência de uso de água (EUA) e a qualidade dos frutos. A condutância estomática nas fases de floração e de frutificação apresentou menor limitação sob os tratamentos 125 e 150\%ETo. Destaca-se que estes tratamentos elevaram em $83 \%$ a massa fresca de fruto por planta, em comparação ao tratamento $50 \%$ ETo. O tratamento $150 \%$ ETo proporcionou maior eficiência instantânea de uso de água na fase de floração, ao passo que o tratamento $125 \%$ ETo culminou na mesma resposta durante a frutificação. O tratamento com lâmina de $125 \%$ da ETo na ausência de cobertura morta estabeleceu o limiar máximo de EUA, enquanto o tratamento 50\%ETo sem cobertura morta assegurou a obtenção do limiar mínimo de EUA. Sob o tratamento $125 \%$ ETo obteve-se maior SS e pH, ao passo que o tratamento $150 \%$ ETo com cobertura dos vasos apresentou maior Ratio e menor acidez total.
\end{abstract}

Termos para indexação: Physalis Peruviana L.; Estresse hídrico; Condutância estomática; Fotossíntese; Produtividade de frutos.

\footnotetext{
'Agronomist, Ph.D, Professor Researcher, State University of Ponta Grossa (UEPG), Ponta Grossa - PR, Brasil. Email: eduardo.agnellos@ gmail.com $^{(\text {ORCID 0000-0002-1393-4166) }}$

${ }^{2}$ Agronomist, Ph.D, Professor Researcher, State University of Ponta Grossa (UEPG), Ponta Grossa - PR, Brasil. Email: rayub@uepg.br (ORCID 0000-0003-3240-8417)

${ }^{3}$ Agronomist, State University of Ponta Grossa (UEPG), Ponta Grossa - PR, Brasil. E-mail: lzangela2@gmail.com ${ }^{\text {(ORCID 0000-0002-5603-2963) }}$ ${ }^{4} \mathrm{PhD}$ Student in Agronomy of State University of Ponta Grossa (UEPG) Ponta Grossa - PR, Brazil. Email: isabelaleticiapessenti@gmail.com (ORCID 0000-0002-5176-3134)
}

${ }^{5}$ Agronomist, Ph.D, Professor Researcher, State University of Ponta Grossa (UEPG), Ponta Grossa - PR, Brasil. abelmont@uepg.br ${ }^{(\mathrm{ORCID}}$ 00000002-1673-9841) 


\section{Introduction}

The crop of cape gooseberry (Physalis peruviana) belongs to the Solanaceous family, and South America is considered to be its center of origin, and currently Colombia is the world major producer and exporter. Such a crop draws attention from consumer market due to its sweet flavor at maturity, nutritional characteristics and human health benefits, as the antioxidant capacity of polyphenols present in its fruits (PUENTE et al., 2011; BRAVO et al., 2015).

Cape gooseberry is a perennial plant of indeterminate growth and develops properly at temperatures varying from 8 to $20^{\circ} \mathrm{C}$, relative humidity between 70 to $80 \%$ and rainfall distribution between 1000 to $1800 \mathrm{~mm}$ annually (TAPIA and FRIES, 2007). It is an excellent choice for small and medium farmers, with the possibility to be grown on pots under a greenhouse condition (RODRIGUES et al. 2013).

Over the last decades, the greenhouse production has grown worldwide (TÜZEL and ÖZTEKIN, 2017). This expansion happens, among others factors, as a function of major control of production environment, plant protections over extreme weather events, increase of plant yield, water economy, and higher water use efficiency (CRITTEN and BAILEY, 2002; KITTAS et al., 2017).

Plants of cape gooseberry cultivated under a greenhouse have shown greater vegetative development and total commercial fruit production in relation to grown ones at field conditions (ZEIST et al., 2014). In protected environments, the proper water replenishment is indispensable to reach high yields. However, knowledge on irrigation scheduling for cape gooseberry under such a system is scarce, which might lead to low water use efficiencies at a commercial scale.

The low water availability for plants affects various metabolic processes. In this particular situation, the stomata close nearly completely, which limits the $\mathrm{CO}_{2}$ assimilation and leaf transpiration rates (ZEGBEDOMÍNGUEZ et al., 2003; FLEXAS et al., 2004; PEREZMARTIN et al., 2014). Under extreme cases, the primary photosynthetic apparatus might be compromised, affecting therefore $\mathrm{CO}_{2}$ assimilation (CATONI et al., 2017). As a response, plants have shown a lower morphological development (PORTES et al., 2006), flower and fruit falls (OSAKABE et al., 2014), and alterations on fruits quality (ZHANG et al., 2017).

On cape gooseberry plants, Deveci and Celik (2016) observed that water deficit reduced the leaf water potential, with enhancement of damage on membrane of leaf cells along with reduction of chlorophyll content. In studies dealing with different levels of irrigation based on evapotranspiration calculated by the class A pan approach, Alvarez-Herrera et al. (2012) observed that the least irrigation coefficient promoted major crack of fruits of cape gooseberry.

The use of mulch on the soil surface guarantees the maintenance of soil moisture, by reducing losses from evaporation, and thus enhance water use efficiency (QIN et al., 2015). The coverage with plant residues is a viable alternative of application, especially under greenhouse conditions at tropical regions, by preventing the soil from garnering an excessive heat within the soil control volume and also by providing low costs of acquisition (BRANDENBERGER and WIEDENFELD, 1997; QIN et al., 2015).

In this view, the current study aimed at assessing crop physiological responses, yields, water use efficiency and fruit quality of cape gooseberry grown under greenhouse conditions as a function of different irrigation depths taking into account either the presence or absence of mulching on the pots under scrutiny.

\section{Materials and Methods}

The experiment was conducted in a greenhouse belonging to the State University of Ponta Grossa, Ponta Grossa - PR, under the geographical coordinates of $25^{\circ}$ $05^{\prime} \mathrm{S}$ and $50^{\circ} 09^{\prime} \mathrm{W}$, with altitude average of $970 \mathrm{~m}$. The local climate is classified as $\mathrm{Cfb}$ by Köppen classification - mesothermal humid subtropical climate (PEEL at al. 2007). The greenhouse is covered with EVA film of 150 microns and climatized with a system pad-fan.

A completely randomized design was used, on a factorial scheme of $4 \times 2$, with 4 replicates, totalizing thirty-two experimental units. The first source of variation was four irrigation depths of $50 \%, 100 \%, 125 \%$, and $150 \%$ of reference evapotranspiration (ETo) via class A pan approach. The second source of variation was the presence or absence of oat plant residue (mulching) on the pots. At every 15 days the pots were randomized inside the greenhouse.

To fill up the $12 \mathrm{~L}$ pots, a substrate composed of pine bark (75\%) and vermiculite (25\%) was used. It was connected to a plastic tube at the pot base which was directed to bottles of $600 \mathrm{~mL}$ in order to collect drainage. The pots were placed on wooden pallets with $0.15 \mathrm{~m}$ height, and bottles on the ground, allowing for a geometric differential of $0.15 \mathrm{~m}$ between the bottles and the base of the pots.

On September $30^{\text {th }}$ of 2016 , tree plugs of cape gooseberry with two expanded leaves were transplanted. Fifteen days after transplant (DAT), the most vigorous plants were selected and then the remaining plats were thinned. Owing to the shrubby habit of cape gooseberry, the plants were tutored with wooden piles of $1.50 \mathrm{~m}$ height and were pruned, especially steams inward directed, conducting the plants on a "V" form.

At 52 DAT a topdressing fertilization at the dose 
of $3.05 \mathrm{~g}$ of yellow Kristalon ${ }^{\mathrm{TM}}$ per pot was adopted. The fertilization of cape gooseberry was based on tomato recommendation, as indicated by Muniz (2011). During the crop growing season, we observed the occurrence of aphids, which was controlled by means of the use of Nim oil at a $1.5 \%$ concentration.

In order to replenish water lost from pots, the reference evapotranspiration (ETo) was established every two days through a class A pan method. The Class A pan was placed on a wooden pallet with $0,15 \mathrm{~m}$ height. The pan was allocated inside the greenhouse and near the experiment. The ETo was obtained applying the equation: $\mathrm{ETo}=\mathrm{ECA} \times \mathrm{Kp}$, where ECA is the evaporation of class A pan (ECA), and $\mathrm{Kp}$ is the pan coefficient (DOORENBOS and PRUITT 1977). The average speed of the fans installed above the class A pan was 2-5 $\mathrm{m} \mathrm{s}^{-1}$ After defining ETo, we calculated the necessary water volume for the treatments, and with the support of a measuring cylinder we proceeded the application of water to the pots. The irrigation was performed in the morning under an irrigation frequency of two days. During the first 15 DAT the irrigation depth was similar for all treatments, under an application of water amounts corresponding to $100 \%$ of ETo. Such a procedure was performed to favor the establishment of plants on the pots. After 15 DAT the irrigation depths were applied for each treatment $(50 \%, 100 \%, 125 \%$ and $150 \%$ of ETo). ETo depicts the atmosphere evaporative demand in such a way as to define the amount of water to be applied to production fields throughout the whole crop growing season at the right moment at a given specific-site.

The gas exchanges assessment was made with a portable infrared gas analyzer (IRGA), model LI 6400XT (LICOR), with an area of the chamber of $0.0006 \mathrm{~m}^{2}$, density of photons photosynthetically active fixed at $1200 \mu \mathrm{mol} \mathrm{m}^{-2} \mathrm{~s}^{-1}$ and flow rate of $500 \mu \mathrm{mol} \mathrm{s}^{-1}$. The third and/or fourth leaf not shaded from the apex to the base were sampled. The measurements were done at 28 days after transplant (DAT) (vegetative growth stage), 56 DAT (flowering - anthesis), and 105 DAT (fructification - fruits maturity) (Ramírez et al., 2013), starting at 10h00min and finishing at $11 \mathrm{~h} 40 \mathrm{~min}$, always on days under a clear sky.

The assessed parameters in the current study were the rate of $\mathrm{CO}_{2}$ assimilation $\left(A, \mu \mathrm{mol} \mathrm{CO} \mathrm{CO}_{2}^{-2} \mathrm{~s}^{-1}\right)$, the stomatal conductance $\left(g s, \mathrm{~mol} \mathrm{H}_{2} \mathrm{O} \mathrm{m}^{-2} \mathrm{~s}^{-1}\right)$, and leaf transpiration $\left(E, \mathrm{mmol} \mathrm{H}_{2} \mathrm{O} \mathrm{m}^{-2} \mathrm{~s}^{-1}\right)$. From $A$ and $E$ the instantaneous water-use efficiency ( $\mathrm{WUE}_{\text {inst }}, \mu \mathrm{mol} \mathrm{CO}_{2}$ mmol $\mathrm{H}_{2} \mathrm{O}^{-1}$ ) was calculated (Condon et al., 2002).

The fruits were harvested mature in accordance with the scale indicated by ICONTEC (1999), and also by the bright yellow color criterion (SBRUSSI et al., 2014). The harvest started at 110 DAT and came to completion at 155 DAT. During harvest we counted the fruits and determined the fresh mass of fruit (FMF), along with fresh mass of fruits per plant (FMFP) using an analytical scale with centesimal precision (model Shimadzu ATX224).
The water use efficiency (WUE) was obtained by dividing the FMFP by the irrigated volume applied to each pot. After the harvest and weighting of fruits, the fruits were conditioned on paper bags and placed in an ultra-freezer (at $-20^{\circ} \mathrm{C}$ ) to provide sequential physicochemical analyses.

To evaluate the content of soluble solids (SS), the berries were grounded and a digital bench-top refractometer coupled to an automatic temperature compensation gadget was used. The titrable acidity (AT) was obtained by titration of the juice of fruits with $\mathrm{NaOH} 1 \mathrm{~N}$ standardized solution on semiautomatic titrator, with titration end point of $\mathrm{pH}=8.2$. The Ratio was established by means of the relationship between SS and AT. To determine vitamin C oxalic acid was taken into consideration as an extractant, in compliance with the criterion described by Benassi and Antunes (1988).

The data were submitted to a descriptive analysis and to the application of Shapiro-Wilk test with the purpose of examining the residuals normality, as well as the application of Bartlett's test to verify the homogeneity of variances. Data that did not have normal distribution were normalized by making use of the software R (R Core Team, 2016). After such a descriptive analysis and normalization of the data, analysis of variance with the application of $\mathrm{F}$ test was performed. If $\mathrm{F}$ was significant at a level of $5 \%$ of probability, regression analyses were proceeded for irrigation depths in conjunction with the Tukey test at $5 \%$ of significance for mulching treatments.

\section{Results and Discussion}

Reference evapotranspiration and irrigated volume - Figure 1 depicts the variation of the reference evapotranspiration (ETo) plus the volume of water applied at each irrigation event under different treatments. The average value with the standard deviation of ETo inside the greenhouse throughout the whole crop growing season corresponded to $2.76 \pm 0.83 \mathrm{~mm}^{\text {day }}{ }^{-1}$.

Owing to variations of the irrigated volume under different treatments (Figure 1), it is highlighted the limitation of water replenishment to the plants submitted to an irrigation depth of $50 \%$ of ETo, which revealed that at any event of irrigation the water volume to be applied was above a $150 \mathrm{~mL}$ pot $^{-1}$ threshold. The total volume applied under the influence of each treatment adopted was of $7.23,14.47,18.08$ along with $21.70 \mathrm{~L} \mathrm{pot}^{-1}$ under the treatments $50,100,125$ e $150 \%$ de ETo, respectively.

Foliar gas exchanges - The variance analyses of the physiologic effects are illustrated in Table 1. It was found that there is no significant effect of interaction between irrigation depths and mulching. The adoption of mulching affected significantly at a level of $p<0,05$ the WUE $_{\text {inst }}$ at 28 DAT (Table 1), with plants grown on pots 
with mulching reaching the highest $\mathrm{WUE}_{\text {inst }}(3.24 \mu \mathrm{mol}$ $\mathrm{CO}_{2} \mathrm{mmol} \mathrm{H}^{-1} \mathrm{O}^{-1}$ ) compared to the absence of mulching $\left(2.83 \mu \mathrm{mol} \mathrm{CO} \mathrm{CO}_{2} \mathrm{mmol} \mathrm{H}_{2} \mathrm{O}^{-1}\right)$. We observed that the presence of mulching raises the value of $A$ at 105 DAT $\left(9.14 \mu \mathrm{mol} \mathrm{CO} \mathrm{m}^{-2} \mathrm{~s}^{-1}\right)$ in comparison to the absence of mulching $\left(7.39 \mu \mathrm{mol} \mathrm{CO} \mathrm{m}^{-2} \mathrm{~s}^{-1}\right)$.

The irrigation depths altered the physiological measurements at 56 and 105 DAT at a level of $p>0,05$ (Table 1), where the best regression fit was the quadratic model (Figure 2). The foliar gases exchange at 28 DAT were not affected by treatments. Thus, the adoption of $50 \%$ of ETo for water supply was suitable for the cape gooseberry.

At 56 and 105 DAT the plants of cape gooseberry subjected to water replenishments of $125 \%$ and $150 \%$ of ETo culminated into the lowest stomata resistance (Figure 2). On both measurements, the low water availability provided by the treatment $50 \%$ of ETo triggered restrictions on stomatal opening (ZEGBE-DOMÍNGUEZ et al., 2003; Perez-Martin et al., 2014), whilst such a treatment indicated average values of stomatal resistance equivalent to 0.29 and $0.13 \mathrm{~mol} \mathrm{H}_{2} \mathrm{O} \mathrm{m}^{-2} \mathrm{~s}^{-1}$ at 56 and 105 DAT, respectively. As a consequence of the increase in stomata resistance, the gas exchanges of the leaves were affected in turn (FLEXAS et al., 2004; PEREZ-MARTIN et al., 2014; CATONI et al., 2017), with a reduction of $A$ and $E$ of plants exposed to a water replenishment of $50 \%$ of ETo.

At the flowering stage (56 DAT) the plants expressed the maximum $A$, highlighting the influence of the treatments 125 and $150 \%$ of ETo, which showed average values of 23.30 and $24.18 \mu \mathrm{mol} \mathrm{CO} \mathrm{m}^{-2} \mathrm{~s}^{-1}$, respectively (Figure 2). At fructification phenological stage we observed a decrease in the $A$ as opposed to the flowering; however, the treatments 125 and $150 \%$ of ETo remained with mean values higher than those ones observed under the treatment $50 \%$ of ETo.

The $\mathrm{WUE}_{\text {inst }}$ demonstrated significant effects at $p<0,05$ on the assessments made at 56 and 105 DAT (Table 2), with a better regression fit ascribed to a quadratic model (Figure 2). At 56 DAT the treatment $150 \%$ of ETo reached a maximum $\mathrm{WUE}_{\text {inst }}\left(3.76 \mu \mathrm{mol} \mathrm{CO}_{2} \mathrm{mmol} \mathrm{H}_{2} \mathrm{O}^{-1}\right)$, whereas at 105 DAT the treatment $125 \%$ of ETo showed a maximum $\mathrm{WUE}_{\text {inst }}\left(3.16 \mu \mathrm{mol} \mathrm{CO} \mathrm{mmol} \mathrm{H}_{2} \mathrm{O}^{-1}\right)$.

The result of $\mathrm{WUE}_{\text {inst }}$ indicates that the irrigation depths of 125 and $150 \%$ of ETo favor the $A$ up to the same proportion of water transpired (CONDON et al., 2002), which turns out to be extremely desirable at production fields to enhance commercial yields (JAIMEZ et al.,2005). Such a biological response is strongly correlated with stomata conductance (GUO, et al., 2006) and consequently with availability of water to the crop (OSAKABE et al., 2014).

Yield and water use efficiency - Table 2 illustrates the values of $\mathrm{F}$ of the components related to the yield, fruit quality, and water-use efficiency. Number of fruits per plant (NFP), fresh mass of fruit (FMF) and fresh mass of fruits per plant (FMFP) not showed significant differences for the interaction between irrigation depth and mulching. The irrigation depths promoted significant effects at $p<0,01$ to NFP and FMFP and at a level of $p<0,05$ to the FMF.

The NFP and FMFP showed best fit to the quadratic regression model (Figure 3). Thus, the cape gooseberry submitted to irrigation depths of $50 \%$ of ETo reduces approximately $84 \%$ of NFP and $83 \%$ of FMFP in relation to the treatments $125 \%$ and $150 \%$ of ETo. In a study dealing with a water deficit of 75 and $50 \%$ of ETo on tomato crop grown at greenhouse conditions (WANG and XING, 2017) compared to an arid natural environment, taking into account water management via class A pan approach (MAHADEEN et al., 2011), we came up with significant reductions in productivity in comparison to systems with replenishments of $100 \%$ of ETo; however at levels way below the observed ones in our specific work.

Under the condition of water stress ( $50 \%$ of ETo), the stomatal limitation took place and consequently reductions in $\mathrm{CO}_{2}$ assimilation (Figure 2) were reported, with direct negative impacts on crop yield (OSAKABE et al., 2014). Nuruddin et al. (2003) highlighted that water deficit in the soil intensifies reductions in the number and fresh mass of fruits per plant of tomato at protected environments, especially whenever water deficit occurs during the flowering stage.

The irrigation depths caused alterations on FMF, with the best fit to the linear regression model (Figure 3). It was noticed increments in the fresh mass of fruits of cape gooseberry as a response to the increase of irrigation depth, highlighting that the treatment of $150 \%$ of ETo $\left(2.92 \pm 0.19 \mathrm{~g}\right.$ fruit $\left.^{-1}\right)$ brought about an increment in FMF of $14 \%$ in comparison to the treatment $50 \%$ of ETo. The amplitude of FMF of under the application of treatments $100 \%, 125 \%, 150 \%$ of ETo was quite similar to the one reported by Yildiz et al. (2015), who found values varying from 2.734 to $3.091 \mathrm{~g}_{\text {fruit }}{ }^{-1}$.

Zegbe-Domíngues et al. (2003), carrying out trials with tomato crop under controlled environmental conditions, observed that the reduction of $50 \%$ of the irrigation depth compared to the control treatment caused a decrease in the fresh mass of fruits. Similar effects were also reported by Ozbahce and Tari (2010); Patanè et al. (2011). Thus, increases of yields in plants grown under proper soil water supply conditions $(125 \%$ and $150 \%$ of ETo) were obtained as a response to substantial increments in NFP and FMF.

The effect of the interaction of sources of variation on water use efficiency presented the best fit to the quadratic model of polynomial regression (Figure 3). The maximum value was observed at the irrigation depth of $125 \%$ of ETo and under absence of mulching (13.07 
$\left.\mathrm{g} \mathrm{L}^{-1}\right)$. We verified that the cape gooseberry subjected to a severe water deficit ( $50 \%$ of ETo) suffered a decrease in WUE (4.38 e $5.15 \mathrm{~g} \mathrm{~L}^{-1}$ under the treatments with and without mulching on pots, respectively). Ozbahce and Tari (2010) and Zhang et al., (2017) found similar outcomes with tomato crop under severe water deficit conditions.

The use of mulching reduced by 19\% WUE in comparison with the treatment without mulching (Table 2). Mukherjee et al. (2012), studying tomato crop yield and physiological responses to water, Lordan et al. (2015) working with peach, and Qin et al. (2015) with maize and oat crops, reported increments in water use efficiency under the presence of mulching along with plastic covering the soil at production fields. Conversely, such an effect was not observed on the cape gooseberry grown at greenhouse conditions.

Fruit quality - The interactions between mulching and irrigation depths promoted significant effects $(p<0.05)$ for the titrable acidity of fruits (AT) and Ratio. The soluble solids (SS), $\mathrm{pH}$ and Ratio showed significant effects to irrigation depth, however vitamin $\mathrm{C}$ was not affected by the sources of variation in our particular study (Table 3).

The effect of interaction on AT and Ratio was observed only at the treatments with mulching, with the best fit of both variables attributed to a quadratic regression model (Figure 4). The irrigation depth of $150 \%$ of ETo provided the least value of titrable acidity ( $0.535 \%$ citric acid) and consequently led to the highest Ratio (33.21). Lima et al. (2012) obtained the highest AT and Ratio varying from 0.62 to $0.78 \%$ and 17.26 to 24.59 , respectively, by conducting experimental trials taking into account different planting dates in Southern Brazil.
Silva et al. (2016) obtained mean values of AT and Ratio corresponding to $1.76 \%$ and 5.58 , respectively, focusing on a $P$. peruviana specie grown under different types of soil coverage.

The irrigation depths altered the $\mathrm{SS}$ and $\mathrm{pH}$ of the fruits, with the best fit to the linear regression and quadratic polynomial models, respectively (Figure 3 ). Puente et al. (2011) compiled several studies and cited values of the SS on fruits of cape gooseberry varying from 13.73 and $14.30^{\circ}$ Brix. Lima et al. (2012) verified that the SS varied from 13.47 to $15.25^{\circ}$ Brix for different harvest times in Southern Brazil. Generally, the $\mathrm{pH}$ of fruits was low, with the treatment of $125 \%$ of the ETo showing the mean greatest value corresponding to 3.05 . Yildiz et al. (2015) and Silva et al. (2016) reported mean $\mathrm{pH}$ values for fruits of $P$. peruviana of 4.47 to 6.07 and 4.06, respectively.

By applying different irrigation depths based on the evapotranspiration at a greenhouse condition, Macêdo \& Alvarenga (2005) came across similar results, with an increment in SS of tomato as a response to the increase in irrigation depths. On the other hand, Zhang et al. (2017) applied different irrigation depths under field conditions and came to the conclusion that both SS and vitamin C of tomato decreased as a function of intensification of water stress in the soil. In our current study, significant effects of irrigations depths on the content of vitamin $\mathrm{C}$ of the fruits of cape gooseberry were not detected.

The mean value of vitamin $\mathrm{C}$ verified in the experiment (18.55 mg 100g, Table 3) was near the lowest limit indicated by Puente et al. (2011), who cites values varying from 20.00 to $43.00 \mathrm{mg} 100 \mathrm{~g}$ of pulp ${ }^{-1}$. Bravo et al. (2015) highlights that ascorbic acid content of cape gooseberry fruit is strongly affected by cultivar.
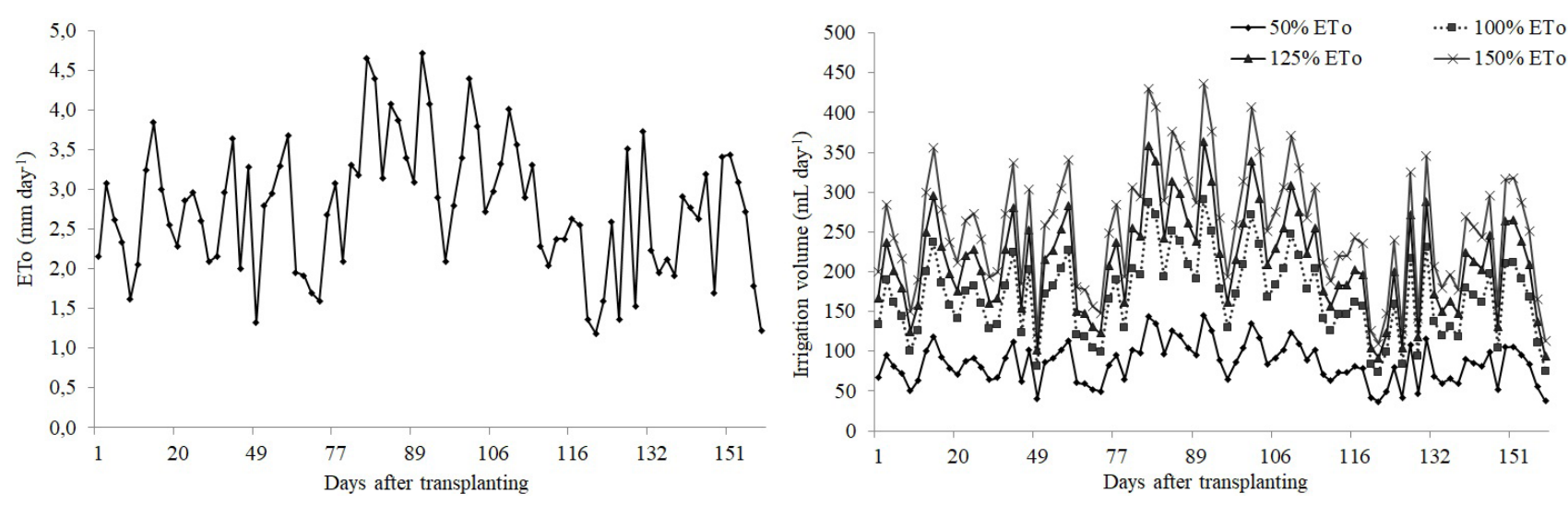

Figure 1. Variation of the reference evapotranspiration $\left(\mathrm{ETo}, \mathrm{mm}^{-1 a y^{-1}}\right)$, measured via class A pan in the greenhouse, and volume of irrigation $\left(\mathrm{mL} \mathrm{day}^{-1}\right)$ to different treatments during the cultivation cycle of cape gooseberry, Ponta Grossa, Brazil, 2017. 
Table 1. Analysis of variance to net photosynthesis $\left(\mathrm{A}, \mu \mathrm{mol} \mathrm{CO} 2 \mathrm{~m}^{-2} \mathrm{~s}^{-1}\right)$, stomatal conductance $\left(g s, \mathrm{~mol} \mathrm{H}_{2} \mathrm{O} \mathrm{m}{ }^{-2}\right.$ $\mathrm{s}^{-1}$ ), leaf transpiration $\left(E, \mathrm{mmol} \mathrm{H}_{2} \mathrm{O} \mathrm{m}^{-2} \mathrm{~s}^{-1}\right.$ ), and instantaneous water-use efficiency (WUE $\mathrm{inst} \mu \mathrm{mol} \mathrm{CO}_{2} \mathrm{mmol}_{2} \mathrm{O}^{-1}$ ) at 28, 56 and 105 days after transplant (DAT) of cape gooseberry, cultivated on pots with different irrigation depths (ID) and mulching of oat residues under greenhouse conditions in Ponta Grossa-PR, 2017.

\begin{tabular}{|c|c|c|c|c|c|}
\hline S.V. & & $A$ & $g s$ & $E$ & WUE $_{\mathrm{in}}$ \\
\hline \multicolumn{6}{|c|}{$28 \mathrm{DAT}$} \\
\hline & With & 13.52 & 0.31 & 4.26 & $3.24 \mathrm{a}$ \\
\hline Mulching (M) & Without & 12.99 & 0.34 & 4.71 & $2.83 \mathrm{~b}$ \\
\hline $\mathrm{F}_{\mathrm{calc}} \mathrm{M}$ & & $0.63^{\text {ns }}$ & $1.32^{\mathrm{ns}}$ & $1,64^{\mathrm{ns}}$ & $5.26^{*}$ \\
\hline $\mathrm{F}_{\text {calc }}$ ID & & $1.28^{\mathrm{ns}}$ & $0.92^{\mathrm{ns}}$ & $1,13^{\mathrm{ns}}$ & $2.25^{\mathrm{ns}}$ \\
\hline $\mathrm{F}_{\text {calc }} \mathrm{M} \times \mathrm{ID}$ & & $1.30^{\mathrm{ns}}$ & $0.18^{\mathrm{ns}}$ & $0.89^{\text {ns }}$ & $0.20^{\mathrm{ns}}$ \\
\hline \multirow[t]{2}{*}{ C.V. (\%) } & & 14.25 & 21.20 & 22.16 & 16.28 \\
\hline & & 56 DAT & & & \\
\hline \multirow{2}{*}{ Mulching (M) } & With & 18,04 & 0,40 & 5,96 & 3,24 \\
\hline & Without & 19,13 & 0,42 & 6,04 & 2,90 \\
\hline $\mathrm{F}_{\text {calc }} \mathrm{M}$ & & $3,76 \mathrm{~ns}$ & $0,24^{\text {ns }}$ & $0,05^{\text {ns }}$ & $3,49 \mathrm{~ns}$ \\
\hline $\mathrm{F}_{\text {calc }}$ ID & & $182,93 *$ & $4,98^{*}$ & $5,07 *$ & $26,19 *$ \\
\hline $\mathrm{F}_{\text {calc }} \mathrm{M} \times \mathrm{ID}$ & & $2,15^{\mathrm{ns}}$ & $1,68^{\mathrm{ns}}$ & $1,75^{\mathrm{ns}}$ & $3,52^{\mathrm{ns}}$ \\
\hline \multirow[t]{2}{*}{ C.V. $(\%)$} & & 8,48 & 16,96 & 17,69 & 16,73 \\
\hline & & 105 DAT & & & \\
\hline \multirow{2}{*}{ Mulching (M) } & With & $9,14 \mathrm{a}$ & $1,13^{\mathrm{T}}$ & $2,10^{\mathrm{T}}$ & $1,85^{\mathrm{T}}$ \\
\hline & Without & $7,39 \mathrm{~b}$ & $1,11^{\mathrm{T}}$ & $1,99^{\mathrm{T}}$ & $1,82^{\mathrm{T}}$ \\
\hline $\mathrm{F}_{\text {calc }} \mathrm{M}$ & & $4,20 * *$ & $1,54^{\mathrm{ns}}$ & $1,73^{\text {ns }}$ & $0,21^{\mathrm{ns}}$ \\
\hline $\mathrm{F}_{\text {calc }}$ ID & & $29,12^{*}$ & $6,98 *$ & $8,17^{*}$ & $14,44 *$ \\
\hline$\frac{\text { calc }}{\mathrm{F}_{\text {calc }}} \mathrm{M}$ x ID & & $0,40^{\text {ns }}$ & $0,38^{\text {ns }}$ & $0,53^{\text {ns }}$ & $0,76^{\mathrm{ns}}$ \\
\hline C.V. (\%) & & 13,99 & 4,52 & 11,86 & 9,90 \\
\hline
\end{tabular}

Averages followed with different letters on the column represents significant differences. * Significant at $\mathrm{p}<0.01 ; * *$ Significant at $\mathrm{p}<0.05$; ${ }^{\mathrm{n}} \mathrm{No}$ significant; C.V., coefficient of variation. S.V., Source of variation. ${ }^{\mathrm{T}}$ Transformed values.

Table 2. Analysis of variance to the number of fruits per plant (NFP), fresh mass of fruits per plant (FFMP), fresh mass of fruit (MFF), and water-use- efficiency (WUE) of cape gooseberry cultivated on pots, with different irrigation depths (ID) and mulching, under greenhouse conditions in Ponta Grossa-PR, Brazil, 2017.

\begin{tabular}{|c|c|c|c|c|c|}
\hline \multirow{2}{*}{ S.V. } & & NFP & FMFP & FMF & WUE \\
\hline & & - & g plant $^{-1}$ & $\mathrm{~g} \mathrm{frut}^{-1}$ & $\mathrm{~g} \mathrm{~L}^{-1}$ \\
\hline \multirow{2}{*}{ Mulching (M) } & With & 53,06 & 151,47 & 2,84 & $8,55 \mathrm{~b}$ \\
\hline & Without & 59,05 & 168,55 & 2,86 & $10,52 \mathrm{a}$ \\
\hline $\mathrm{F}_{\text {calc }} \mathrm{M}$ & & $1,69^{\mathrm{ns}}$ & $1,80^{\mathrm{ns}}$ & $0,31^{\mathrm{ns}}$ & $5,85^{*}$ \\
\hline $\mathrm{F}_{\text {calc }}$ ID & & $45,26^{*}$ & $52,18^{*}$ & $3,68 * *$ & $9,05 *$ \\
\hline $\mathrm{F}_{\text {calc }} \mathrm{M} \times \mathrm{ID}$ & & $1,72^{\mathrm{ns}}$ & $1,71^{\mathrm{ns}}$ & $0,18^{\mathrm{ns}}$ & $8,05^{*}$ \\
\hline C.V. $(\%)$ & & 23,31 & 22,50 & 8,49 & 14,11 \\
\hline
\end{tabular}

Averages followed with different letters on the column represents significant differences. * Significant at $\mathrm{p}<0.01 ; * *$ Significant at $\mathrm{p}<0.05 ;{ }^{\text {ns }} \mathrm{No}$ significant; C.V., coefficient of variation. S.V., Source of variation. ${ }^{\mathrm{T}}$ Transformed values. 
Table 3. Analysis of variance for the total soluble solids (SS), titrable acidity (AT), pH, Ratio and vitamin $\mathrm{C}$ of the fruits of cape gooseberry cultivated on pots, with different irrigation depths (ID) and mulching, under greenhouse conditions in Ponta Grossa-PR, Brazil, 2017.

\begin{tabular}{ccccccc}
\hline \multirow{2}{*}{ S.V. } & & SS & AT $^{\mathrm{T}}$ & $\mathrm{pH}$ & Ratio & Vit. C \\
\cline { 2 - 6 } & & ${ }^{\circ}$ Brix & $\%$ ác. cítrico & & SS/AT & mg 100g \\
\hline \multirow{2}{*}{ Mulching $(\mathrm{M})$} & With & 15,32 & 1,36 & 2,68 & 20,06 & 19,66 \\
& Without & 15,17 & 1,35 & 2,95 & 18,45 & 17,44 \\
\hdashline $\mathrm{F}_{\text {calc }} \mathrm{M}$ & $0,28^{\text {ns }}$ & $0,03^{\text {ns }}$ & $3,47^{\text {ns }}$ & 0,65 & $0,84^{\text {ns }}$ \\
\hline $\mathrm{F}_{\text {calc }} \mathrm{ID}$ & $3,19^{*}$ & $3,46^{*}$ & $3,64^{* *}$ & $5,56^{* *}$ & $1,12^{\text {ns }}$ \\
\hline $\mathrm{F}_{\text {calc }} \mathrm{M} x \mathrm{ID}$ & $1,24^{\text {ns }}$ & $6,24^{* *}$ & $1,84^{\text {ns }}$ & $5,06^{* *}$ & $2,26^{\text {ns }}$ \\
\hline C.V. $(\%)$ & 3,99 & 4,56 & 14,52 & 19,33 & 15,29
\end{tabular}

Averages followed by different letters on columns represent significant differences. ${ }^{* *}$ Significant at $\mathrm{p}<0.01$; ${ }^{*}$ Significant at $\mathrm{p}<0.05$; ${ }^{\text {ns }}$ No significant; C.V., coefficient of variation. S.V., Source of variation. ${ }^{\top}$ Transformed values by $Y_{t}=\sqrt{Y_{o b s}+1} Y_{t}=\sqrt{Y_{\text {obs }}+1}$.
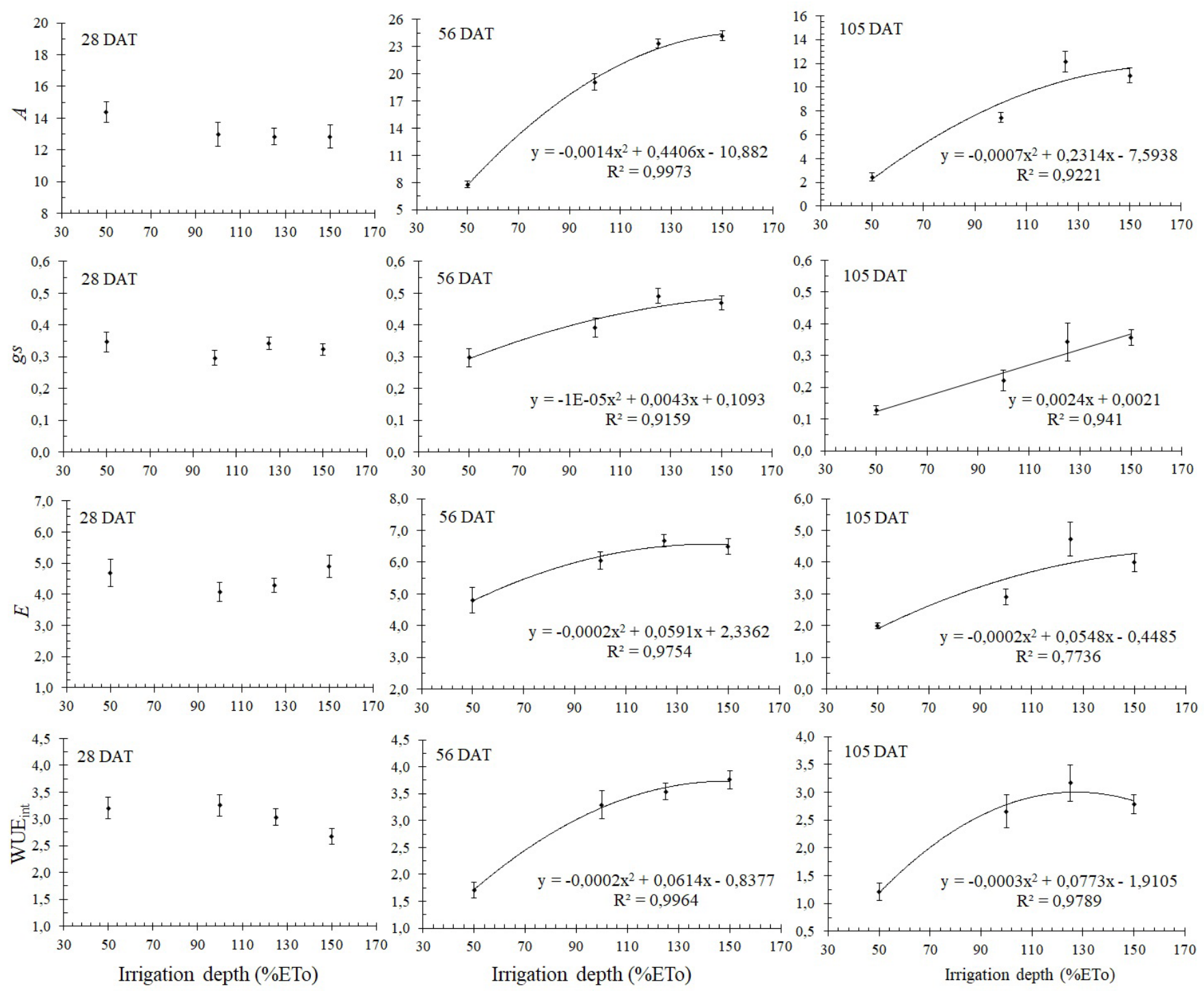

Figure 2. Regression analysis of the effect of irrigation depth, based on the percentage of reference evapotranspiration (ETo), on the rate of $\mathrm{CO}_{2}$ assimilation $\left(A, \mu \mathrm{mol} \mathrm{CO} \mathrm{m}^{-2} \mathrm{~s}^{-1}\right)$, stomatal conductance $\left(g s, \mathrm{~mol} \mathrm{H}_{2} \mathrm{O} \mathrm{m}^{-2} \mathrm{~s}^{-1}\right)$, leaf transpiration $\left(E, \mathrm{mmol} \mathrm{H}_{2} \mathrm{O} \mathrm{m}^{-2} \mathrm{~s}^{-1}\right.$ ) and instantaneous water-use efficiency ( $\mathrm{WUE}_{\text {inst }}, \mu \mathrm{mol} \mathrm{CO} \mathrm{Cmol}_{2} \mathrm{O}^{-1}$ ), at 28, 56, and 105 days after transplant (DAT) of cape gooseberry cultivated on pots, under greenhouse conditions in Ponta Grossa-PR, 2017. 

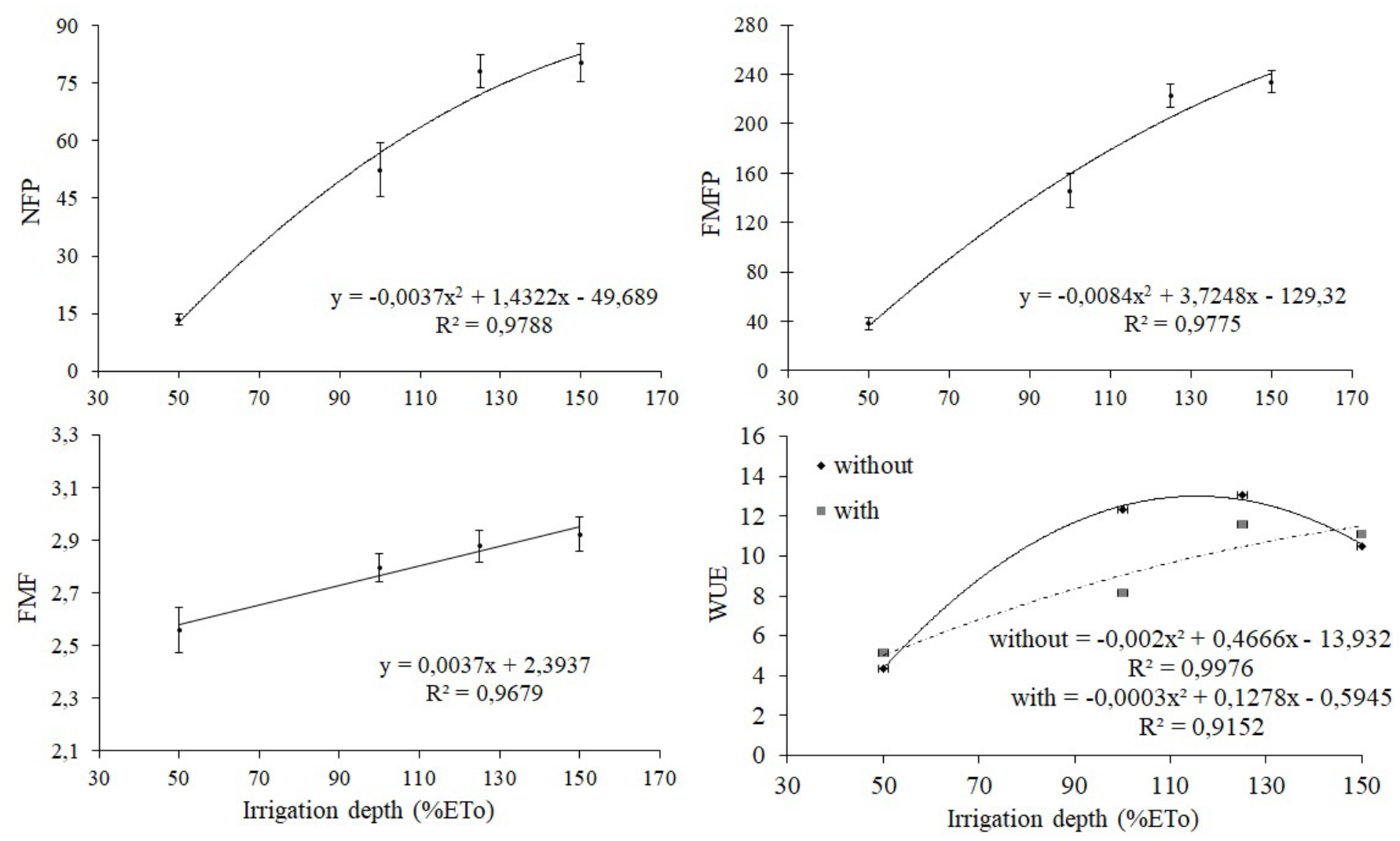

Figure 3. Analyses of regression to irrigation depths (\% of reference evapotranspiration (ETo)), on the number of fruits per plant (NFP), fresh mass of fruits per plant (FMFP, g plant ${ }^{-1}$ ) and fresh mass of fruit (FMF), and interaction between irrigation depths and mulching (with and without) for water use efficiency (WUE, $\mathrm{g} \mathrm{L}^{-1}$ ) on cape gooseberry, cultivated on pots under greenhouse conditions, in Ponta Grossa-PR, Brazil, 2017.
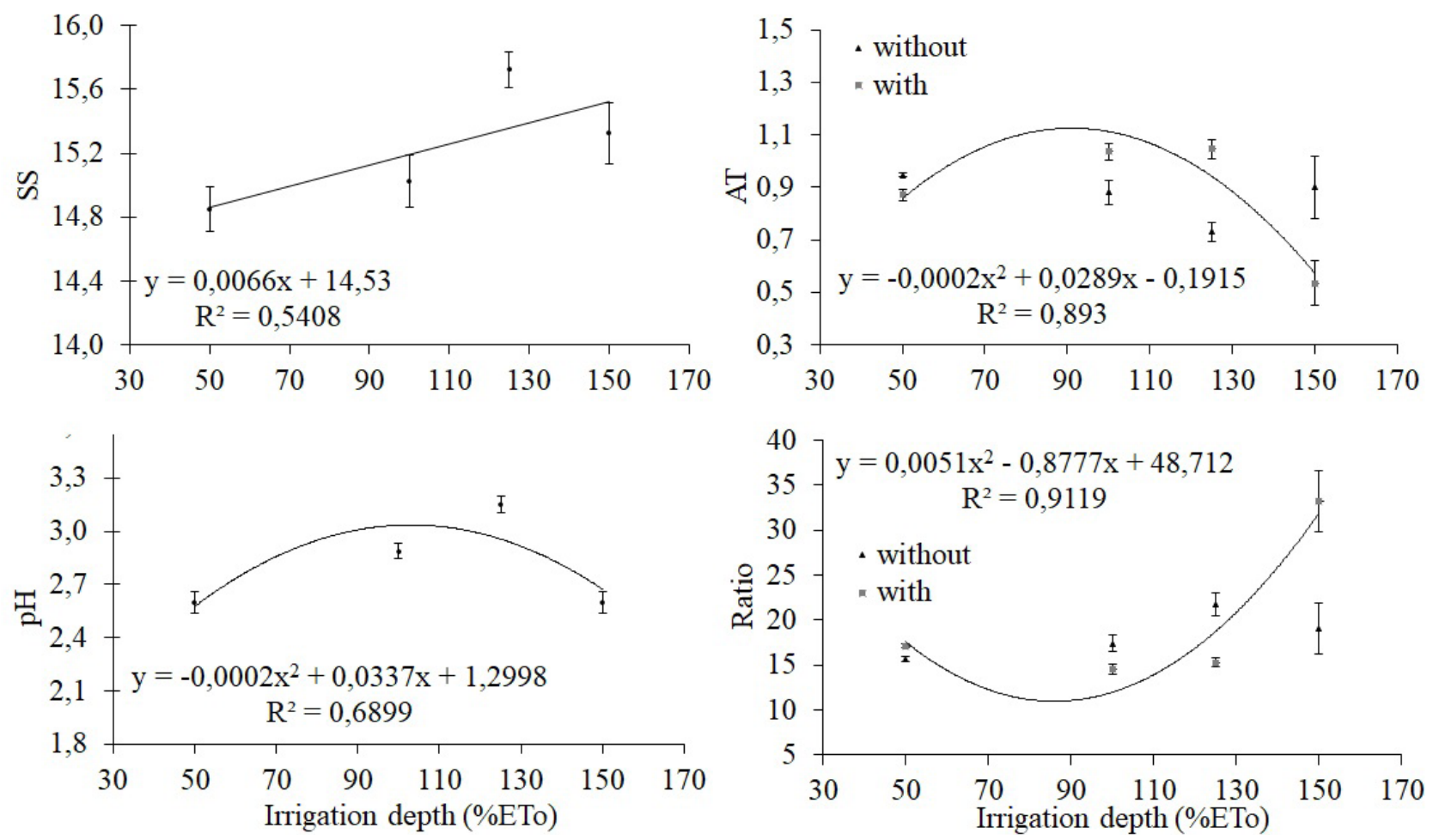

Figure 4. Analysis of regression for irrigation depths (\% of reference evapotranspiration (ETo), with and without mulching, on the soluble solids (SS, ${ }^{\circ}$ Brix), titrable acidity (AT, \% citric acid), Ratio (SS/AT) and the $\mathrm{pH}$ of the fruits of cape gooseberry, cultivated under greenhouse conditions, in Ponta Grossa-PR, Brazil, 2017. 


\section{Conclusions}

Under the experimental conditions of this work, it is possible to affirm that up until 28 days after transplant of the cape gooseberry the irrigation depth based on 50\% of ETo did not alter the leaf gas exchanges. Throughout the flowering, irrigation depths of $125 \%$ and $150 \%$ of ETo lead to a lower stomata restriction, impinging upon major rates of $\mathrm{CO}_{2}$ assimilation, leaf transpiration, and intrinsic water-use efficiency.

The cape gooseberry irrigated with 125 and $150 \%$ of ETo showed the highest yields. The assumption that the use of oat mulching raises the efficiency of water use has not been confirmed; however, plants irrigated with $125 \%$ ETo without mulching evidenced the highest water use efficiency.

The irrigation management and mulching remarkably affect the quality of the fruits of cape gooseberry, when irrigation depth of $150 \%$ of ETo with mulching is taken into consideration, resulting in the lowest value of total acidity in conjunction with the highest Ratio. The irrigation depths governed the content of soluble solids and also $\mathrm{pH}$, with the treatment of $125 \%$ of ETo providing the highest values for both variables.

\section{References}

ALVAREZ-HERRERA, J.G.; BALAGUERA-LÓPEZ, H.E.; FISCHER, G. Effect of irrigation and nutrition with calcium on fruit cracking of the cape gooseberry (Physalis peruviana L.) in the three strata of the plant. Acta Horticulturae, The Hague, v.928, p.163-170, 2012.

BENASSI, M.T.; ANTUNES, A.J. A comparison of meta-phosphoric and oxalic acids as extractant solutions for the determination of vitamin $\mathrm{c}$ in selected vegetables. Arquivos de Biologia e Tecnologia, Curitiba, v.31, n.4, p. $507-513,1988$.

BRADENBERG, L.; WIENDEFELD, B. Physical characteristics of mulches and their impact on crop response and profitability in muskmelon production. HortTechnology, Alexandria, v. 7, p. 165-169, 1997.

BRAVO, K.; SEPULVEDA-ORTEGA, S.; LARAGUZMAN, O.; NAVAS-ARBOLEDA, A.; OSORIO, E. Influence of cultivar and ripening time on bioactive compounds and antioxidant properties in Cape gooseberry (Physalis peruviana L.). Journal of the Science of Food and Agriculture, New York, v.95, n.7, p.1562-1569, 2015.
CATONI, R.; GRATANI, L.; BRACCO, F.; GRANATA, M.U. How water supply during leaf development drives water stress response in Corylus avellane saplings. Scientia Horticulturae, Amsterdam, v.214, p.122-132. 2017.

CONDON, A.G.; RICHARDS R.A.; REBETZKE G.J.; FARQUHAR G.D. Improving intrinsic water-use efficiency and crop yield. Crop Science, Madison v.42, p.122-131, 2002.

CRITTEN, D.L.; BAILEY, B.J. A review of greenhouse engineering developments during the 1990s. Agricultural and Forest Meteorology, Amsterdam, v.112, p.1-22, 2002 .

DEVECI, M.; CELIK, A. The effects of different water deficiency on physiological and chemical changes in Cape gooseberry (Physalis peruviana L.) which were grown in greenhouse conditions. Scientia Horticulturae, Amsterdam, v.14, n.2, p.260-265, 2016.

DOORENBOS, J.; PRUITT, W.O. Crop water requirements. Rome: FAO, 1977. (Irrigation and Drainage Paper, 24).

FLEXAS. J.; BOTA, J.; LORETO, F.; CORNIC, G.; SHARKEY, T.D. Diffusive and metabolic limitations to photosynthesis under drought and salinity in C(3) plants. Plant Biology, Hoboken. v.6, n.3, p. 269-279, 2004.

GUO, S.; ZHOU, Y.; SONG, N.; SHEN, Q. Some physiological processes related to water use efficiency of higher plants. Agricultural Sciences in China, Beijing, v.5, n.6, 2006. 403-411.

ICONTEC - Instituto Colombiano de Normas Técnicas y Certificación. NTC 4580: frutas frescas, uchuva, especificaciones. Bogotá: ICONTEC, 1999. 15p.

JAIMEZ, R.E.; RADAB, F.; GARCÍA-NÚÑEZB, C.; AZÓCARB, A. Seasonal variations in leaf gas exchange of plantain cv. 'Hartón' (Musa AAB) under different soil water conditions in a humid tropical region. Scientia Horticulturae, Amsterdam, v.104, p.79-89, 2005.

KITTAS, C.; KATSOULAS, N.; BARTZANA, T. Structures: designer, technology and climate control. In: BAUDOIN, W., et al. (ed.). Good agricultural practices for greenhouse vegetable production in the South East European countries. FAO: Rome, 2017. p.29-52. (Plant Production and Protection Paper, 230). 
LIMA, C.S.M.; GALARÇA, S.P.; BETEMPS, D.L.; RUFATO, A.R.; RUFATO, L. Avaliação física, química e fitoquímica de frutos de physalis, ao longo do período de colheita. Revista Brasileira de Fruticultura, Jaboticabal, v.34, n.4, p.1004-1012, 2012.

LORDAN, J.; PASCUAL, M.; VILLAR, J.P.; FONSECA, F.; PAPIÓ, J.; MONTILLA, V.; RUFAT, J. Use of organic mulch to enhance water-use efficiency and peach production under limiting soil conditions in a three-yearold orchard. Spanish Journal of Agricultural Research, Madrid, v.13, n.4, e0904, 2015.

MACÊDO, L.S.; ALVARENGA, M.A.R. Efeitos de lâminas de água e fertirrigação potássica sobre o crescimento, produção e qualidade do tomate em ambiente protegido. Ciência e Agrotecnologia, Lavras, v.29, n.2, p.296-304, 2005.

MAHADEEN, F.Y.; MOHAWESH, O.E.; AL-ABSI, K.; AL-SHAREEF, W. Effect of irrigation regimes on water use efficiency and tomato yield (Lycopersicon esculentum Mill.) grown in an arid environment. Archives of Agronomy and Soil Science, Berlin, v.57, p.105-114, 2011.

MUKHERJEE, A.; SARKAR, S.; CHAKRABORTY, P.K. Marginal analysis of water productivity function of tomato crop grown under different irrigation regimes and mulch managements. Agricultural Water Management, Amsterdam, v.104, p.121-127, 2012.

MUNIZ, J.; KRETZCHMAR, A.A.; RUFATO, L.; PELIZZA, T.R.; MERCHI, T.; DUARTE, A.E.; LIMA, A.P.F.; GARANHANI, F. Sistemas de condução para o cultivo de physalis no planalto catarinense. Revista Brasileira de Fruticultura, Jaboticabal, v.33, n.3, p.830838, 2011.

NURUDDIN, M.M.; MADRAMOOTOO, C.A.; DODDS, $\mathrm{G}$ Effects of water stress at different growth stages on greenhouse tomato yield and quality. HortScience, Alexandria v.38, n.7, p.1389-1393, 2003.

OSAKABE, Y.; OSAKABE, K.; SHINOZAKI, K.; TRAN, L.S. Response of plant to water stress. Frontiers in Plant Science, Lausanne, v.5, n.86, p.1-8, 2014.

OZBAHCE, A.; TARI. A.F. Effects of different emitter space and water stress on yield and quality of processing tomato under semi-arid climate conditions. Agricultural Water Management, Amsterdam, v.97, p.1405-1410, 2010.
PATANÈ, C.; TRINGALI, S.; SORTINO, O. Effects of deficit irrigation on biomass, yield, water productivity and fruit quality of processing tomato under semi-arid Mediterranean climate conditions. Scientia Horticulturae, Amsterdam, v.129, n.4, p.590-596, 2011.

PEEL, M.C.; FINLAYSON, B.L.; MCMAHON, T.A. Updated world map of the Köppen-Geiger climate classification. Hydrology and Earth System Sciences, Göttingen, v.11, p.1633-1644, 2007.

PEREZ-MARTIN, A.; MICHELAZZO, C.; TORRESRUIZ, J.M.; FLEXAS, J.; FERNÁNDEZ, J.E.; SEBASTIANI, L.; DIAZ-ESPEJO, A. Regulation of photosynthesis and stomatal and mesophyll conductance under water stress and recovery in olive trees: correlation with gene expression of carbonic anhydrase and aquaporins. Journal of Experimental Botany, Oxford, v.65, n.12, p.3143-3156, 2014.

PORTES, M.T.; ALVES, T.H.; SOUZA, G.M. Water deficit affects photosynthetic induction in Bauhinia forficata Link (Fabaceae) and Esenbeckia leiocarpa Engl. (Rutaceae) growing in understory and gap conditions. Brazilian Journal of Plant Physiology, Campinas, v.18, n.4, p.491-512, 2006.

PUENTE, L.A.; PINTO-MUÑOZ, C.A.; CASTRO, E.S.; CORTÉS, M. Physalis peruviana Linneus, the multiple properties of a highly functional fruit: A review. Food Research International, Amsterdam, v.44, n.7, p.17331740, 2011.

QIN, W.; HU, C.; OENEMA, O. Soil mulching significantly enhances yields and water and nitrogen use efficiencies of maize and wheat: a meta-analysis, Scientific Reports, London, v.5, n.16210, p.1-13, 2015.

R CORE TEAM. R: a language and environment for statistical computing. Vienna: R Foundation for Statistical Computing, 2016.

RAMÍREZ, F.; FISCHER, G.; DAVENPORT, T.L.; PINZÓN, J.C.A.; ULRICHS, C. Cape gooseberry (Physalis peruviana L.) phenology according to the $\mathrm{BBCH}$ phenological scale. Scientia Horticulturae, Amsterdam., v.162, p.39-42, 2013.

RODRIGUES, F.A.; PENONI, E.S.; SOARES, J.D.R.; SILVA, R.A.L.; PASQUAL, M. Caracterização fenológica e produtividade de Physalis peruviana cultivada em casa de vegetação. Bioscience Journal, Uberlândia, v.29, n.6, p.1771-1777, 2013. 
SBRUSSI, C.A.G.; ZUCARELI, C.; PRANDO, A.M.; SILVA, B.V.A.B. Maturation stages of fruit development and physiological seed quality in Physalis peruviana. Revista Ciência Agronômica, Fortaleza, v.45, n.3, p.543549, 2014.

SILVA, D.F.; PIO, R.; SOARES, J.D.R.; VILLA, F.; VILAS BOAS, E.V.B. Light spectrum on the quality of fruits of physalis species in subtropical area. Bragantia, Campinas, v.75, n.3, p.371-376, 2016.

TAPIA, M.; FRIES, A. Guia de campo de los cultivos andinos. Lima: FAO and ANPE, p. 105-112, 2007. Disponível em: http://www.fao.org/docrep/010/ai185s/ ai185s.pdf. Acesso em: 20 out. 2018.

TÜZEL, Y.; ÖZTEKIN, G.B. Crop diversification, management and practical uses. In: BAUDOIN, W., et al. (ed.). Good agricultural practices for greenhouse vegetable production in the South East European countries. Rome: FAO, 2017. p.105-122. (Plant Production and Protection Paper. 230).
WANG, X.; XING, Y. Evaluation of the effects of irrigation and fertilization on tomato fruit yield and quality: a principal component analysis. Scientific Reports, London, v.7, n.350, 1-13, 2017.

YILDIZ, G.; IZLI, N.; ÜNAL, H.; UYLASER, V. Physical and chemical characteristics of goldenberry fruit (Physalis peruviana L.). Journal of Food Science and Technology, New Delhi, v.52, n.4, p.2320-2327, 2015.

ZEGBE-DOMÍNGUEZ, J.A.; BEHBOUDIAN, M.H.; LANG, A., CLOTHIER, B.E. Water relation, growth, and yield of processing tomatoes under partial rootzone drying. Journal of Vegetable Crop Production, Abingdon, v.9, n.2, p.31-40, 2003.

ZEIST,A.R.;ZANIN, D.S.; CHAGAS, R.R.; GIACOBBO, C.L.; RESENDE, J.T.V. Produtividade, desenvolvimento vegetativo e trocas gasosas de Physalis peruviana cultivada em ambiente protegido e a campo. Enciclopédia Biosfera, Goiânia v.10, n.18, p.4015-4023, 2014.

ZHANG, H.; XIONG, Y.; HUANG, G.; XU, X.; HUANG, Q. Effects of water stress on processing tomatoes yield, quality and water use efficiency with plastic mulched drip irrigation in sandy soil of the Heaton Irrigation District. Agricultural Water Management, Amsterdam, v.179, p.205-2014, 2017. 